Volume 2 Issue 1, January-June 2021: PP: 39-56

Faculty of Law, Universitas Lampung, Bandar Lampung, Indonesia.

http://jurnal.fh.unila.ac.id/index.php/constitutionale

P-ISSN: 2723-2492 E-ISSN: 2745-9322

\title{
Indonesian National Army Involvement in Handling Terrorism Action from Legal Perspective
}

\author{
Wilma Silalahi \\ wilma@mkri.id \\ Mahkamah Konstitusi, Indonesia
}

Submitted: 20 January 2021; Reviewed: 3 February 2021; Accepted: 10 April 2021.

\section{Article's Information}

Abstract

Keywords: Army; Legal; Terrorism; Prespective.

DOI:

https://doi.org/10.25041/constitutionale.v2i1.2255

\begin{abstract}
The crime of terrorism is an extraordinary crime against humanity, including a "serious crime" whose number of actions has increased. It requires handling with exceptional measures and "serious measures" with still respecting human values. Thus, what becomes an interesting problem in this research is how to involve the Indonesian National Army in handling acts of terrorism from a legal perspective. This research uses a normative doctrinal method. The Indonesian National Army's involvement in managing acts of terrorism and supported by the prevailing laws and regulations provides a greater sense of security and legal certainty for the community. Also, this research intends to examine that the involvement of the Indonesian National Army in handling acts of terrorism is by applicable regulations. The handling of criminal acts of terrorism requires a juridical basis to create a sense of security and justice. Thus, the Indonesian National Army must maintain the Unitary State of the Republic of Indonesia's territorial integrity and uphold state sovereignty. Therefore, the involvement of the Indonesian National Army in the context of handling acts of terrorism is an aid to
\end{abstract}




the PolicePolice in defending the
independence of the state, maintaining
the territorial integrity of the Unitary
State of the Republic of Indonesia, and
protecting the entire nation and all
spilled Indonesian blood based on
Pancasila and the 1945 Constitution.
The involvement of the Indonesian
National Army in eradicating acts of
terrorism is part of the support for the
National Police, in the context of
carrying out law enforcement operations
that are not Military Operations Apart
from War, unless they develop into acts
of terrorism that threaten the existence of
the Unitary State of the Republic of
Indonesiar or extraordinary
circumstances occurs. This is in line with
the Indonesian National Army's unique
nature (lex specialis) in carrying out its
duties.

\section{A. Introduction}

The aim of the development of the Indonesian nation is as mandated by the Preamble of the 1945 Constitution, namely to protect the entire Indonesian government and all the blood of Indonesia and to promote public welfare, educate the nation's life, and participate in implementing world order based on independence, eternal peace, and social justice, ${ }^{1}$ Therefore, it is necessary to enforce the law consistently and continuously. Meanwhile, as a constitutional state born in the 12th century, which was adopted with the principles of constitutionalism as adhered to by Pancasila and the 1945 Constitution, it is an active/dynamic constitutional state. ${ }^{2}$ Despite the noble ideals of the founding fathers, there are still specific intentions of groups who want to disturb the Indonesian state's security and order, marked by bombing incidents in the Republic of Indonesia's territories. Resulting in the loss of life regardless of the victim, causing widespread fear in the community, loss of independence, and loss of property, which can impact social life, economy, politics, and international relations. ${ }^{3}$ The incident that occurred can be a crime of acts of terrorism, both that threaten the Republic of Indonesia and between countries. The crime of transnational terrorism is a transnational crime, organized, and has a vast network that threatens national and international peace and security. ${ }^{4}$

The crime of terrorism, which is also known as the criminal act of terrorism, is an act that fulfills the elements of a criminal act following statutory regulations. Or the criminal act of

\footnotetext{
${ }^{1}$ Alinea Keempat Pembukaan UUD 1945.

${ }^{2}$ Zulkarnain Ridlwan, Negara Hukum Indonesia Kebalikan Nachtwachterstaat, Fiat Justitia Jurnal Ilmu Hukum, Volume 5, No. 2, May-August 2012.

${ }^{3}$ Ahmad Mukri Aji, Pemberantasan Tindak Pidana Terorisme di Indonesia (Analisis Terhadap UU No. 15 dan 16 Tahun 2003 Berdasarkan Teori Hukum), Jurnal Cita Hukum, Vol. 5, No. 1, Juni 2013, pg. 63.

${ }^{4}$ Elucidation of Law Number 15 of 2003 concerning Stipulation of Government Regulations in Lieu of Law Number 1 of 2002 concerning the Eradication of Criminal Acts of Terrorism into Law (State Gazette of the Republic of Indonesia of 2003 Number 45, Supplement to the State Gazette of the Republic of Indonesia Number 4284, from now on referred to as Law $15 / 2003)$.
} 
terrorism is the activity of any person who deliberately uses violence. ${ }^{5}$ or threats on $^{6}$ violence create or intend to create an atmosphere of terror or fear towards people in a widespread manner or cause mass casualties, by seizing freedom or the loss of life and/or property of others, or causing or causing damage or destruction to vital strategic objects ${ }^{7}$ or the environment or public facilities ${ }^{8}$ Or international facilities, punishable by the death penalty or life imprisonment or imprisonment for a minimum of 4 (four) years and a maximum of 20 (twenty) years or a maximum of life. ${ }^{9}$

Terrorism is an extraordinary crime. ${ }^{10}$ Which require extraordinary measures. ${ }^{11}$ Thus, the crime of terrorism requires eradication efforts ${ }^{12}$ which can rely on normative legal provisions and repressive attitudes of law enforcers and respect human rights values. ${ }^{13}$ Terrorism is a common enemy of mankind, which has recently increased rapidly in number both in Indonesia and globally. ${ }^{14}$ Terrorism can be said as a crime against humanity. ${ }^{15}$ Therefore, eradicating the crime of terrorism cannot use the usual methods as is done in dealing with ordinary crimes in general. In criminal acts of terrorism, threats and criminal acts of violence committed by terrorists are aimed at threatening or threatening acts of violence that threaten life's safety without choosing who will be the victim or what the consequences will be. ${ }^{16}$

Terrorism, which is also a severe crime, requires "serious measures". ${ }^{17}$ State efforts in dealing with terrorism are like fighting offenders with strategies that are not easily known and predictable. ${ }^{18}$ Therefore, it is necessary to regulate terrorism separately and specifically in statutory regulations, including defining terrorism clearly and clearly. ${ }^{19}$ So, this research's interesting issue is how the Indonesian National Army or Tentara Nasional Indonesia (TNI) is involved in handling acts of terrorism from a legal perspective. This issue is interesting, considering that the Revis Bill on the Eradication of Terrorism is currently being discussed.

\footnotetext{
${ }^{5}$ Violence is any act of abuse of physical strength with or without the use of means against the law and causing danger to the body, life, and freedom of a person, including making people unconscious or helpless.

${ }^{6} \mathrm{~A}$ threat is every business and activity, both from within the country and abroad, which is deemed to endanger the country's sovereignty, the territorial integrity of the country, and the safety of the entire country.

${ }^{7}$ Strategic essential objects are areas, places, locations, buildings, or installations which: (a) concern the livelihoods of many people, the dignity of the nation; (b) is a source of state income that has political, economic, social, and cultural values; or (c) concerning very high defense and security.

${ }^{8}$ Public facilities are places that are used for the benefit of the public in general.

${ }^{9}$ Article 6 and Article 7 of Law 15/2003.

${ }^{10}$ Aulia Rosa Nasution, “TERORISME SEBAGAI 'EXTRAORDINARY CRIME’ DALAM PERSPEKTIF HUKUM DAN HAK ASASI MANUSIA ," Jurnal Hukum Responsif, accessed February 10, 2021, http://jurnal.pancabudi.ac.id/index.php/hukumresponsif/article/view/165.

${ }^{11}$ Samsul Arifin, "Perlindungan Hukum Terhadap Anak Dalam Tindak Pidana Terorisme," Jurnal Panorama Hukum 5, no. 1 (June 5, 2020): 49-62, https://doi.org/10.21067/jph.v5i1.4317.

${ }^{12}$ Eradicating the criminal act of terrorism is a policy and strategic step to strengthen public order and public safety while upholding law and human rights, not discriminating based on ethnicity, religion, race, or between groups, as regulated in Article 2 of the law. 15/2003.

13 Ahmad Jazuli, "STRATEGI PENCEGAHAN RADIKALISME DALAM RANGKA PEMBERANTASAN TINDAK PIDANA TERORISME (Prevention Strategy of Radicalism in Order To Wipe Out The Terrorism Crime)," Jurnal Ilmiah Kebijakan Hukum, vol. 10, February 13, 2017, https://doi.org/10.30641/KEBIJAKAN.2016.V10.197-209.

${ }^{14}$ A Faiz Yunus, "Radikalisme, Liberalisme Dan Terorisme: Pengaruhnya Terhadap Agama Islam," Jurnal Online Studi AlQur An 13, no. 1 (January 1, 2017): 76-94, https://doi.org/10.21009/jsq.013.1.06.

${ }_{15}$ Muhammad Arif Setiawan, "Kriminalisasi Terorisme Di Indonesia Dalam Era Globalisasi," Jurnal Hukum IUS QUIA IUSTUM 9, no. 21 (September 21, 2002): 67-86, https://doi.org/10.20885/iustum.vol9.iss21.art6.

${ }^{16}$ Hamzah AL Junaid Jurusan Pendidikan Agama Islam DPK UIM Gazali UIN Alauddin Makassar Alamat and jipang raya, "PERGERAKAN KELOMPOK TERORISME DALAM PERSPEKTIF BARAT DAN ISLAM," Sulesana: Jurnal Wawasan Keislaman, vol. 8, December 1, 2013, https://doi.org/10.24252/.V8I2.1285.

${ }^{17}$ Aji Widiatmaja and Ulul Albab, "Indonesia Di Era Susilo Bambang Yudhoyono (SBY) Dan Joko Widodo: Kebijakan Luar Negeri Di Tengah Dinamika Lingkungan [Indonesia under Susilo Bambang Yudhoyono (SBY) and Joko Widodo: Foreign Policy in the Middle of Regional Strategic Environment Dynamics]," Jurnal Politica Dinamika Masalah Politik Dalam Negeri Dan Hubungan Internasional 10, no. 1 (May 31, 2019): 77-93, https://doi.org/10.22212/jp.v10i1.1313.

${ }_{18}$ Sri Yunanto, Angel Damayanti, Indah Novitasari, Ancaman dan Strategi Penanggulangan Terorisme di Dunia dan Indonesia, Institute For Peace and Security Studies (IPSS) bekerjasama dengan CV. Multi Inovasi Mandiri (MIM), Cetakan I: 2017.

${ }^{19}$ Legal Considerations of the Constitutional Court Decision Number 55 / PUU-XVI / 2018, dated 30 October 2018.
} 
With the outbreak of bomb cases in various regions, is it possible for the PolicePolice without other agencies' help to take preventive measures against criminal acts of terrorism? This simple research does not intend to justify that in dealing with acts of terrorism, TNI must be involved, but it wants to provide a choice of other points of view, although thoughts that overlap with one another cannot be avoided. In this research, a study will be carried out to determine that the involvement of the TNI in handling acts of terrorism from a legal perspective is whether it is constitutionality or unconstitutionality.

This study uses a normative approach with a post-positivism paradigm, which, according to Lincoln and Guba, can lead to a deeper level of understanding of complex social processes replacing experimental approaches in positivism clusters of thought. ${ }^{20}$ Thus, this study uses a normative juridical method ${ }^{21}$ or according to Wignjosoebroto is doctrinal research, ${ }^{22}$ Namely, a study using positivist legis, which states that law is identical to written norms made and promulgated by an authorized institution or official. In this conception, the law is seen as a normative system that is autonomous, closed, and independent of people's lives. Satjipto Rahardjo said this perspective is seeing law as an abstract regulation. His attention will be focused on genuinely autonomous institutions, namely those that can be discussed as separate subjects, regardless of their relation to matters outside the regulation. Its concentration will lead to a normative method and following its analytical discussion, so it is called normative analysis. ${ }^{23}$ Thus, the involvement of the TNI in handling acts of terrorism and supported by the prevailing laws and regulations provides a greater sense of security and legal certainty for the community.

\section{B. Discussion}

According to the Constitutional Court, terrorism is a "generis humanist hostist" or enemy of mankind. As the enemy of mankind, the criminal act of terrorism is a severe crime and endangers the state ideology, state security, state sovereignty, human values, and various aspects of social, national, and state life, as well as transnational, organized, and has a vast network and has specific objectives so that its eradication needs to be carried out precisely, planned, directed, integrated, and continuously based on Pancasila and the 1945 Constitution. ${ }^{24}$ Therefore, terrorism is a common enemy that threatens the whole world and is a threat to human rights, justified both socially and legally. In tackling criminal acts of terrorism, the government strives to prepare a juridical foundation following human civilization's development to be able to provide a sense of security and justice to its citizens.

Sehingga, yang termasuk perbuatan tindak pidana terorisme, antara lain:

1. Any person who deliberately uses violence or threats of violence to create an atmosphere of terror or fear towards people widely or cause mass casualties, by taking away freedom or loss of life and property of others, or causing damage or destruction to objects. Vital strategic objects or the environment or public facilities, or international facilities shall be punished with the death penalty or life imprisonment or imprisonment for a minimum of 4 (four) years and a maximum of 20 (twenty) years. ${ }^{25}$

\footnotetext{
20 See Bambang Setioko, Penggunaan Metoda Grounded Theory Dibawah Payung Paradigma Postpositivistik Pada Penelitian Tentang Fenomena Sosial Perkotaan, Modul, Vol. 11, No. 1, Januari 2011, pg. 2.

${ }^{21}$ Soerjono Soekanto dan Sri Mamudji, Penelitian Hukum Normatif, Jakarta, Raja Grafindo Persada, 1985, pg. 15.

${ }^{22}$ Bambang Sunggono, Metodologi Penelitian Hukum, Jakarta, Raja Grafindo Persada, 1997, pg. 42.

${ }^{23}$ Ibid., pg. 67-68.

${ }^{24}$ Consideration Considering letter an of Law Number 5 of 2018 concerning Amendments to Law Number 15 of 2003 concerning Stipulation of Government Regulations in Lieu of Law Number 1 of 2002 concerning Eradication of Criminal Acts of Terrorism Into Law (State Gazette of the Republic of Indonesia of 2018 Number 92, Supplement to the State Gazette of the Republic of Indonesia Number 6216, from now on referred to as Law 5/2018).

${ }^{25}$ Article 6 Law 15/2003.
} 
2. Any person who deliberately uses violence or threats of violence to create an atmosphere of terror or fear towards people or cause mass casualties by taking away freedom or loss of life or property of others, or to cause damage or destruction to vital strategic objects, or the environment, or public facilities, or international facilities, shall be punished with a maximum imprisonment of life. ${ }^{26}$

3. Anyone who destroys makes unusable, or damages a building for safeguarding air traffic, or thwarts efforts to secure said structure.; 27

4. Any person who causes the destruction, inability to use or damage to the building for safeguarding air traffic, or failure of efforts to secure said building. ${ }^{28}$

5. Any person who knowingly and unlawfully destroys, damages, takes, or removes a sign or device for safeguarding flights, fails the operation of said sign or device, or displays the wrong character or device.; ${ }^{29}$

6. Any person due to their negligence causes the sign or device for security of flight to be destroyed, damaged, taken, or moved or causes the wrong sign or device for flight security to be installed.; ${ }^{30}$

7. Any person who knowingly or unlawfully destroys or makes the aircraft unusable, wholly or partly belonging to another person; ${ }^{31}$

8. Anyone knowingly or unlawfully injures, destroys, incapacitates, or damages aircraft; ${ }^{32}$

9. Anyone due to their negligence causes the aircraft to be damaged, destroyed, unusable, or to damage aircraft; ${ }^{33}$

10. Any person to unlawfully benefit himself or another person, for the insurer to cause a fire or explosion, accidental destruction, damage or render the aircraft responsible for the danger or the insured person unable to use it or the wages to be received for the transportation of the cargo, or the benefit of the cargo, a deposit has been received; ${ }^{34}$

11. Any person in an aircraft with an illegal act seizes or maintains the confiscation or control of the aircraft in flight; ${ }^{35}$

12. Any person in an aircraft by force or threat of violence or other forms of threat seizes or maintains the aircraft's seizure of control in flight.; ${ }^{36}$

13. Everyone commits jointly as a continuation of an evil consensus, is carried out in advance, causes serious injury to a person, causes damage to the aircraft so that it may endanger his flight, is carried out to deprive someone of liberty or continue to deprive someone of liberty; ${ }^{37}$

14. Everyone deliberately and unlawfully commits an act of violence against someone on an airplane in flight if that act could endanger the aircraft's safety.; ${ }^{38}$

15. Any person who knowingly and unlawfully damages an aircraft in service or causes damage to said aircraft which prevents flight or endangers the safety of the flight; ${ }^{39}$

16. Any person who knowingly and unlawfully places or causes him to be placed on an aircraft on service, by any means, a device or material that can destroy an aircraft that

\footnotetext{
${ }^{26}$ Article 7 Law 15/2003.

${ }^{27}$ Article 8 letter a Law 15/2003.

${ }^{28}$ Article 8 letter b Law 15/2003.

${ }^{29}$ Article 8 letter c Law 15/2003.

${ }^{30}$ Article 8 letter d Law 15/2003.

${ }^{31}$ Article 8 letter e Law 15/2003.

${ }^{32}$ Article 8 letter f Law 15/2003.

${ }^{33}$ Article 8 letter g Law 15/2003.

${ }^{34}$ Article 8 letter h Law 15/2003.

${ }^{35}$ Article 8 letter i Law 15/2003.

${ }^{36}$ Article 8 letter j Law 15/2003.

37 Article 8 letter k Law 15/2003.

${ }^{38}$ Article 8 letter 1 Law 15/2003.

${ }^{39}$ Article 8 letter m Law 15/2003.
} 
makes it unable to fly or causes damage to the aircraft, which could endanger security in flight. ${ }^{40}$

17. Everyone commits 2 (two) people or more together, as a continuation of an evil conspiracy, commits premeditatedly, and results in serious injury to a person from the actions referred to in number 14 , number 15 , and number $16 ;{ }^{41}$

18. Every person provides information which he knows to be false and because of that act endangers the safety of the aircraft in flight; ${ }^{42}$

19. Every person onboard an aircraft commits an act that could endanger the safety of the aircraft in flight; ${ }^{43}$

20. Every person on board an aircraft commits acts that may disturb the order and order in the aircraft in flight. ${ }^{44}$

\section{Background on Terrorism Crime}

The factors that cause terrorism, according to Bjorgo, namely: ${ }^{45}$ (1) precondition of terrorism, namely the factors that provide conditions in the long run and then give rise to terrorism; and (2) precipitants of terrorism, are certain specific events or phenomena that directly precede or trigger an act of terrorism. These two factors are further divided into 4 (four) levels, namely:

a. Structural causative factors, namely the causal factors that influence people's lives at the macro-level (abstract), which may unconsciously include: demographic imbalance, globalization, rapid modernization, societal transition, increasing individualism, and uprooted from the roots and alienation in society (atomization), class structure, etc.

b. Factors that cause facilitators (accelerators), namely the factors that cause terrorism to be an attractive option, even though they are not the main drivers of terrorism. For example, the development of mass media in the modern era, the development of transportation, weapons technology, weak state control over its territory, etc.

c. Motivational causes, namely actual dissatisfaction (grievances) experienced at the personal level, motivate a person to act. Ideologies or political leaders can translate causes at the structural level and make them relevant at the motivational level through ideologies to move people to move.

d. The trigger factor, namely the direct cause of the occurrence of a terrorist act. Trigger factors can be in the form of provocative events or certain political events or actions taken by the enemy that cause specific reactions.

According to Angga Putri, the root causes of terrorism or prime movers are, among others: ${ }^{46}$ Radical Islamic ideology, the existence of deprivation conditions such as poverty and low levels of education (although academically there is no empirical evidence that poverty is correlated with terrorism) and ideology is only an intermediate cause, not a root cause. This view then underlies the government in formulating counterterrorism policies, both counterterrorism based on the disruption of networks of terror groups and anti-terrorism, which is still based on the idea of deradicalization counter-radicalization, 'war wins hearts and minds).

\footnotetext{
${ }^{40}$ Article 8 letter $n$ Law 15/2003.

${ }^{41}$ Article 8 letter o Law15/2003.

42 Article 8 letter p Law15/2003.

${ }^{43}$ Article 8 letter q Law15/2003.

${ }^{44}$ Article 8 letter $\mathrm{r}$ Law15/2003.

45 Tore Bjorgo, Root Causes of Terrorism: Myths, Reality, and Ways Forward, New York: Routledge, 2005.

${ }^{46}$ Angga Putri Permata Sari, "Akar Permasalahan Terorisme di Indonesia" Modernisasi, Represi Politik, dan Tujuan Strategis Penggunaan Metode Teror Sebagai Faktor-faktor Struktural dan Agensial yang Berkonstribusi Pada Kemunculan Terorisme di Era Komando Jihad dan Kelompok Usroh, Program Studi Pascasarjana Kajian Terorisme dalam Keamanan Internasional Departemen Ilmu Hubungan Internasional Fakultas Ilmu Sosial dan Ilmu Politik Universitas Indonesia, 2011.
} 
Meanwhile, according to Michael Seno Rahardanto, factors that have the potential to underlie terrorism cases, among others: ${ }^{47}$

1. Perceptions of distributive, procedural, and interactional injustices.

Greenberg argues that there are three types of justice perceptions, namely distributive, procedural and interactional justice. ${ }^{48}$ Distributive justice is concerned with the equitable distribution of resources. In contrast, procedural justice is concerned with granting equal rights to make decisions in resource management, and interactional justice is concerned with applying fair interactions without favoritism. ${ }^{49} \mathrm{In}$ his essay on radicalism in religion, Djamaludin Ancok argues that the perception of injustice is an essential factor that correlates with a radicalism that leads to terrorism. Ancok accused several Western institutions, such as the IMF, World Bank, and WTO, of being the perpetrators of injustice against developing countries in the world. A similar opinion was expressed by Fathali Moghaddam, who is very famous for his theory of Staircase to Terrorism. Moghaddam argues that the roots of terrorism can be traced to perceptions of injustice, whether distributive, procedural, or interactional, without the option to fight diplomatically. Finally, violence is the method chosen as a form of resistance. Moreover, it is supported by factors such as the meaning of the scriptures and the existence of a community that fosters the perception of radicalism.

2. The perceived meaning of holy book verses supports radicalism

Scriptures can be interpreted in various ways, including interpretations that lead to radicalism. By the ideologues of fundamentalism (of any religion), the holy book is considered to provide an absolute and unmatchable mandate. ${ }^{50}$

3. Communities that support or nurture the perception of radicalism.

Philip Zimbardo states that "a barrel filled with vinegar will always turn any vegetable put in it into pickles, regardless of resilience, goodwill, or the genetic condition of the vegetables", that is, the environment exerts a strong influence on shaping individual behavior. ${ }^{51}$ Reserve Battalion 101 is a regiment recruited by the Nazi-German side in World War II. The regiment consisted of 500 (five hundred) middle-aged men who were too old to join the army. The men are "homebodies" who come from good families. None of the members had any military experience, let alone experience torturing or killing people. The middle-aged men were sent to Poland on a special mission to kill as many Jews as possible (but the mission's purpose was not revealed shortly before the men were deployed to the field). The regiment members were given the freedom to resign from the regiment if they were unable to continue their work. When at last the regiment was sent to the field and ordered to kill as many Jews as possible, the regiment members initially showed severe psychosomatic symptoms such as vomiting, nightmares, and trembling. However, within four months, the number of victims killed by the 500 soldiers was 38,000 (thirty-eight thousand). No more psychosomatic or guilty feelings: some members even take photos laughing near the pile of victims' bodies. ${ }^{52}$ This phenomenon shows the magnitude of the community's influence on the formation of

\footnotetext{
${ }^{47}$ Michael Seno Rahardanto, "MENGKAJI SEJUMLAH KEMUNGKINAN PENYEBAB TINDAK TERORISME: KAJIAN SOSIO-KLINIS,” EXPERIENTIA : Jurnal Psikologi Indonesia, vol. 1, November 6, 2012, https://doi.org/10.33508/EXP.V1I1.54.

${ }^{48}$ Fathali M. Moghaddam, "The Staircase to Terrorism a Psychological Exploration," American Psychologist, February 2005, https://doi.org/10.1037/0003-066X.60.2.161.

49 Djamaludin Ancok, Ketidakadilan sebagai sumber radikalisme dalam agama: Suatu analisis berbasis teori keadilan dalam pendekatan psikologi, Jurnal Psikologi Indonesia, 2008, pg. 1-8.

50 J. Nelson-Pallmayer, Is religion killing us?, (Terjemahan: Hatib Rachmawan, Bobby Setiawan), Yogyakarta: Pustaka Kahfi, 2007.

${ }^{51}$ P.G. Zimbardo, A situationist perspective on the psychology of evil: Understanding how good people are transformed into perpetrators, 2004. Dalam A.G. Miller (Ed.), The social psychology of good and evil (21-50), New York: The Guilford Press. 52 Ibid.
} 
individual attitudes, values, and behavior. The power of groups in cultivating radicalism and violence has been proven repeatedly in much scientific literature. ${ }^{53}$

4. Ingroup-Outgroup Polarization

Teori ingroup-outgroup pada awalnya dipopulerkan oleh Henry Tajfel dan John Turner (1979), dan selanjutnya teori ini sering sekali digunakan dalam ranah psikologi, khususnya psikologi sosial. Ingroup mengacu ke kelompok tempat kita (pelaku) menjadi anggotanya, sedangkan outgroup mengacu ke kelompok di luar kita (pelaku). ${ }^{54}$ Riset menunjukkan bahwa seseorang cenderung memiliki bias positif terhadap kelompoknya sendiri (ingroup) dan sebaliknya memiliki bias negatif terhadap kelompok di luar kelompoknya sendiri (outgroup). ${ }^{55}$ Terorisme terbentuk dalam situasi saat polarisasi (pemisahan) kubu ingroup dan outgroup menjadi sedemikian besarnya sehingga setiap kubu mengklaim dirinya sebagai pihak yang "benar" dan mendehumanisasi kubu lawannya sebagai "monster, setan". 56 Demikian pula, di Indonesia, sejumlah kelompok fundamentalis radikal ditengarai memandang pemerintah dan aparat yang mendukung pemerintahan (seperti kepolisian) sebagai kubu "toghut" atau "setan".57

5. Heuristic bias experienced by perpetrators of terrorism.

This idea includes a new concept, which is the original idea of Mirra Noor Milla, ${ }^{58}$ Regarding the process of assessing and making terrorism strategies in Indonesia, by interviewing three Bali Bombing prisoners who were imprisoned in Nusakambangan. By using the basis of Kahneman's Limited Rationality Theory. ${ }^{59}$ Milla interpreted and concluded that the Bali Bombing I terrorism perpetrators tended to be trapped in a heuristic bias. In conditions like this, a person does not get adequate information on the problem's nature and solution. Someone tends to make decisions by relying on heuristic principles. ${ }^{60}$ Heuristics is the human ability to make decisions quickly based on incomplete data, like being able to guess a complete puzzle image based only on some existing pieces. ${ }^{61}$ The strong sense of disappointment caused by the perception of injustice causes some individuals to turn to the closest sources of information obtained, such as scripture and community, which can become a platform for channeling disappointment into a hope against possible resistance. The existence of a charismatic leader figure can lead individuals to submit to conformity pressures in the group. When these conformity pressures fade, for example, when the perpetrators are in prison, it is not uncommon for the perpetrators to feel ashamed and sorry for their actions. ${ }^{62}$

\footnotetext{
${ }^{53}$ P.R. Ehrlich, J. Liu, Some roots of terrorism. Population and Environment, 24(2), 2002, pg. 183-192.

54 H. Tajfel, J. Turner, An integrative theory of intergroup conflict, http://dtserv2. compsy.unijena.de/ss2009/sozpsy_uj/86956663/content.nsf/Pages/58BD3B477ED06679C12

5759B003B9C0F/\$FILE/Tajfel\%20Turner\%201979.pdf, 1979, accessed on 24 October 2020.

55 D. Druckman, Nationalism, and War: A social-psychological perspective, 2001. Dalam D. J. Christie, R.V. Wagner, D.D.N.

Winter (Ed.), Peace, conflict, and violence: Peace psychology for the $21^{\text {st }}$ century (49-65), New Jersey: Prentice-Hall.

${ }^{56}$ Fathali Moghaddam, Op.cit.

${ }^{57}$ L. Hertanto, Abu Dujana anggap polisi toghut, http://news.detik.com/read/2007/06/23/173328/797030/10/abu-dujanaanggap-polisi-toghut, 2007, diunduh 24 Okrober 2020.

${ }_{58}$ Mirra Noor Milla, Bias heuristik dalam proses penilaian dan pengambilan strategi terorisme, Jurnal Psikologi Indonesia, Vol. 1, 2008, pg. 9-21.

59 D. Kahneman, Maps of bounded rationality: A perspective on intuitive judgment and choice. Diunduh dari http://www.nobelprize.org/nobel_prizes/economics/laureates/2002/kahnemann- lecture.pdf, 2002, accessed on 24 October 2020.

${ }^{60}$ Mirra Noor Milla, Op.cit., pg. 11.

${ }^{61} \mathrm{~K}$. Cherry, What is a heuristic?, http://psychology.about.com/od/hindex/g/ heuristic.htm, 2012, accessed on 24 October 2020.

${ }^{62}$ Mirra Noor Milla, Op.cit., pg. 11.
} 
6. Disappointment with the practice of the democratic system.

In his book, Jan Aritonang ${ }^{63}$ Reports the history of encounters with Christians and Muslims in Indonesia, from the Portuguese, Spanish, and VOC (Dutch) colonial era to the "Reformasi" era. Aritonang highlighted the disappointment of some fundamentalists who reject or disapprove of Indonesia's practice of the democratic system. In exchange, these circles offer a system of government based on a particular religion radically. By many individuals who adhere to this fundamentalist ideology, the current government system in Indonesia is considered an "evil" system, sometimes termed "toghut" or "devil", so it must be fought. ${ }^{64}$

\section{Counterterrorism}

Deradicalization

The deradicalization approach is a counterweight to the law enforcement approach using criminal law facilities (overcoming crimes with a disciplinary process). Through a non-penal approach, repressive actions against radicalism and various forms of terrorism are carried out from the upstream, namely starting from the root causes of the growth of various thoughts of radicalism and efforts to overcome them without using criminal law. ${ }^{65}$

Deradicalization, according to Abu Rockhmad, is a continuation of work after knowing the roots of radicalism. Deradicalization is also intended as a precautionary measure before radicalism is formed. ${ }^{66}$

Meanwhile, according to Petrus R. Golose, deradicalization efforts to neutralize radical ideas through an interdisciplinary approach. Meanwhile, deradicalization of terrorism is manifested in a program of reorienting motivation, education, resocialization, and striving for social welfare and equality with other communities for those who have been involved in terrorism and for sympathizers, so that a sense of nationalism arises and is willing to participate as Indonesian citizens. ${ }^{67}$ Besides, according to Agus Surya Bakti, deradicalization is an effort to reduce radical activities and neutralize radical ideas for those involved in terrorists and their sympathizers and members of society who have been exposed to certain radical ideologies. The general purpose of deradicalization is to make terrorists or groups that commit violence willing to leave or disengage from terrorist acts and activities. Meanwhile, the specific objectives are: (1) to make terrorists want to leave acts of terrorism and violence; (2) radical groups support moderate and tolerant thinking; (3) radicals and terrorists can support national programs in building the life of the nation and state within the framework of the Republic of Indonesia. ${ }^{68}$

Deideologisasi

The state seeks to remove ideologies from within terrorists or stop the process of spreading ideologies.$^{69}$ Ideology attempts to stop understanding and spreading radical Islamic ideology that terrorist groups own. Thus, ideology is the primary key in awakening or the process of reorienting terrorist thoughts so that they can return to the true understanding of Islam.

\section{Institutions/Agencies in Handling Terrorism}

In handling acts of terrorism as described above, it is necessary to regulate the authorized institutions in handling them, namely, among others:

\footnotetext{
${ }^{63}$ Jan S. Aritonang, Sejarah perjumpaan Kristen dan Islam di Indonesia. Jakarta: BPK Gunung Mulia, 2006.

${ }^{64}$ L. Hertanto, Op.cit.

${ }^{65}$ Muhammad Ali Zaidan, Pemberantasan Tindak Pidana Terorisme (Pendekatan Kebijakan Kriminal), Seminar Nasional Hukum Universitas Negeri Semarang, Volume 3, Nomor 1, 2017, pg. 161.

${ }^{66}$ Abu Rokhmad, "RADIKALISME ISLAM DAN UPAYA DERADIKALISASI PAHAM RADIKAL," Walisongo: Jurnal Penelitian Sosial Keagamaan 20, no. 1 (May 30, 2012): 79, https://doi.org/10.21580/ws.20.1.185.

67 Petrus Reinhard Golose, Deradikalisasi Terorisme. Humanus Soul Approach dan Menyentuh Akar Rumput, Jakarta: Yayasan Pengembangan Ilmu Kepolisian (YPKIK), 2010, pg. 82.

68 Agus Surya Bakti, Deradikalisasi Nusantara, Perang Semesta Berbasis Kearifan Lokal, Melawan Radilisasi dan Terorisme, Jakarta: Daulat Press, 2016, pg. 142.

${ }^{69}$ Petrus Reinhard Golose, Op.cit.
} 


\section{a. The National Counterterrorism Agency or Badan Nasional Penanggulangan Terorisme (BNPT)}

The agency that manages matters in counterterrorism is the National Counterterrorism Agency, which is under and responsible to the President. ${ }^{70}$ BNPT was formed based on Presidential Regulation Number 46 of 2010 concerning the National Counterterrorism Agency, which was later amended by Presidential Regulation Number 12 of 2012 concerning Amendments to Presidential Regulation Number 46 of 2010 concerning the National Counterterrorism Agency (State Gazette of the Republic of Indonesia of 2012 Number 30). The formation of the BNPT is a National Policy for Combating Terrorism in Indonesia, developing by the Counterterrorism Coordination Desk (DKPT) in 2002. ${ }^{71}$ BNPT is the center for crisis analysis and control, which functions as a facility for the President to determine policies and measures for handling crises, including mobilizing resources in dealing with terrorism. ${ }^{72}$ Also, the BNPT has several functions: ${ }^{73}$

a. Formulating policies, strategies, and national programs in the field of counterterrorism;

b. Coordinating related government agencies in implementing and implementing policies in the field of counterterrorism;

c. Implementing policies in counterterrorism by forming a Task Force consisting of elements from related government agencies following their respective duties, functions, and authorities.

\section{b. Indonesian National Army or Tentara Nasional Indonesia (TNI)}

TNI, as a means of defense of the Unitary State of the Republic of Indonesia (NKRI), is tasked with implementing state defense policies to uphold the sovereignty of the state, nation, carry out military operations for war and military operations other than war, and participate actively in regional and international peacekeeping tasks. ${ }^{74}$ The TNI acts as a state instrument in the defense sector in carrying out its duties based on state policies and political decisions. ${ }^{75},{ }^{76}$ consisting of the Army, Navy, and Air Force who carry out their duties in an integrated or combined manner under the Commander's leadership. ${ }^{77}$ TNI as a means of state defense has a function as: ${ }^{78}$ (a) antidote ${ }^{79}$ against every form of military threat and the armed threat from outside and within the country against the sovereignty, territorial integrity, and safety of the nation; (b) the actor ${ }^{80}$ against every form of threat as referred to in paragraph (1) letter a; and (c) restorer ${ }^{81}$ against the state's security condition, which was disturbed due to security chaos. Following its function, the TNI is a significant component of the national

\footnotetext{
70 Article 43E ayat (1) UU 5/2018.

${ }^{71}$ Reni Windiani, Peran Indonesia Dalam Memerangi Terorisme, Jurnal Ilmu Sosial, Vol. 16, No. 2, Edisi Juli - Desember 2017, pg. 143.

72 Article 43E paragraph (2) Law No. 5/2018.

${ }^{73}$ Article 2 Government Regulation 46/2010.

${ }^{74}$ Law Number 34 of 2004 concerning the Indonesian National Army (State Gazette of the Republic of Indonesia of 2004 Number 127, Supplement to the State Gazette of the Republic of Indonesia Number 4439, from now on referred to as Law $34 / 2004)$

${ }^{75}$ State political policies and decisions are political policies of the government and the DPR, formulated through the working relationship mechanism between the government and the DPR, such as consultation meetings and work meetings under statutory regulations.

${ }^{76}$ Article 5 Law 34/2004

77 Article 4 paragraph (1) Law 34/2004.

${ }^{78}$ Article 6 paragraph (1) Law 34/2004.

${ }^{79}$ The deterrent is the real force of the TNI, which has a psychological aspect to be taken into account by the opponent so that it discourages the opponent's intention as well as prevents the opponent's intention that will threaten the country's sovereignty, territorial integrity, and the safety of the nation.

${ }^{80}$ The perpetrators are TNI forces capable of destroying forces that threaten the country's sovereignty, territorial integrity, and national safety.

${ }^{81}$ The restorer is the strength of the TNI together with other government agencies to assist the function of the government to restore the state's security condition, which has been disturbed due to security chaos due to war, rebellion, communal conflict, riots, terrorism, and natural disasters
} 
defense system. ${ }^{82}$ Meanwhile, the TNI has the main task of enforcing the sovereignty of the state, ${ }^{83}$ maintain territorial integrity ${ }^{84}$ NKRI, which is based on Pancasila and the 1945 Constitution, and protects the entire nation and all Indonesian blood from threats and disturbances to the integrity of the government and state ${ }^{85},{ }^{86}$ that's executed through: ${ }^{87}$ (a) military operations for war; ${ }^{88}$ (b) operasi militer selain perang, yaitu untuk: (1) mengatasi gerakan separatis bersenjata; (2) mengatasi pemberontakan bersenjata; (3) mengatasi aksi terorisme; (4) mengamankan wilayah perbatasan; (5) mengamankan objek vital nasional yang bersifat strategis ${ }^{89}(6)$ melaksanakan tugas perdamaian dunia sesuai dengan kebijakan politik luar negeri; (7) mengamankan Presiden dan Wakil Presiden beserta keluarganya; (8) memberdayakan wilayah pertahanan ${ }^{90}$ dan kekuatan pendukungnya secara dini sesuai dengan sistem pertahanan semesta; (9) membantu tugas pemerintahan di daerah; ${ }^{91}$ (10) membantu Kepolisian Negara RI dalam rangka tugas keamanan dan ketertiban masyarakat yang diatur dalam undang-undang; (11) membantu mengamankan tamu negara setingkat kepala negara dan perwakilan pemerintah asing yang sedang berada di Indonesia; (12) membantu menanggulangi akibat bencana alam, pengungsian, dan pemberian bantuan kemanusiaan; (13) membantu pencarian dan pertolongan dalam kecelakaan (search and rescue); serta (14)

${ }^{82}$ Article 6 paragraph (2) Law 34/2004.

${ }^{83}$ Upholding state sovereignty is maintaining state power to carry out self-government free from threats.

${ }^{84}$ Maintaining territorial integrity is maintaining the unity of the state's territory with all its contents, on land, sea, and air, the boundaries of which are determined by law.

85 Threats and disruptions to the integrity of the nation and state include:

a. aggression in the form of the use of armed force by other countries against the sovereignty of the country, territorial integrity, and the safety of the entire nation or informs and methods, including:

1. invasion in the form of the use of armed force;

2. bombardment in the form of the use of other weapons;

3. blockade of ports, beaches, airspace, or the entire territory of the Republic of Indonesia;

4. armed attacks by other countries against elements of the land, sea, and air units;

5. the existence or actions of elements of foreign armed forces within the territory of the Republic of Indonesia that are contrary to the provisions or agreements that have been agreed upon;tindakan suatu negara yang mengizinkan penggunaan wilayahnya oleh negara lain untuk melakukan agresi atau invasi terhadap NKRI;

6. sending armed groups or mercenaries to carry out acts of violence in the territory of the Republic of Indonesia;

7. The President determines other threats.

b. territorial violations committed by other countries;

c. armed rebellion, that is, an armed movement against the legitimate government;

d. sabotage from certain parties to destroy important installations and vital national objects;

e. espionage carried out by other countries to seek and obtain military secrets;

f. armed acts of terror committed by international terrorists or in collaboration with domestic terrorists or by domestic terrorists

g. security threats at sea or in the air of Indonesian national jurisdiction, which certain parties commit, can be in the form of:

1. piracy or robbery;

2. smuggling of weapons, ammunition, and explosives or other materials which may endanger the safety of the nation;

3. Illegal fishing or theft of wealth at sea.

h. Communal conflicts that occur between groups of people can endanger the safety of the nation.

${ }^{86}$ Article 7 paragraph (1) Law 34/2004.

${ }^{87}$ Article 7 paragraph (2) Law 34/2004.

${ }^{88}$ Military war operations are all forms of deployment and use of TNI force to fight against the military forces of other countries that carry out aggression against Indonesia and/or in armed conflict with another country or more, which are preceded by a declaration of war and are subject to international war laws.

${ }^{89}$ National vital objects that are strategic in nature are objects related to the lives of the people, the dignity of the nation, and national interests, which are determined by government decisions.

${ }^{90}$ Empowering the defense area is:

a. assisting the government to prepare the national potential to become a defense force which is prepared in advance covering the area of defense and its supporting forces, to carry out military operations for war, the implementation of which is based on the interests of state defense following the universal defense system;

b. assisting the government in organizing compulsory basic military training for citizens following statutory regulations;

c. help the government empower the people as a supporting force.

${ }^{91}$ Helping the task of the government in the regions is to assist the implementation of government functions in conditions and situations that require the TNI's facilities, tools, and capabilities to solve the problems that are being faced, including helping to overcome the consequences of natural disasters, rehabilitating infrastructure, and overcoming problems due to strikes and communal conflicts. 
membantu pemerintah dalam pengamanan pelayaran dan penerbangan terhadap pembajakan, perompakan, dan penyelundupan.

The task of the TNI in overcoming acts of terrorism is part of military operations other than war, which are carried out under the main duties and functions of the TNI. Thus, the main task of the TNI is to maintain the Republic of Indonesia's territorial integrity and uphold the country's sovereignty. Law 34/2004 provides a legal umbrella for the TNI to be involved in overcoming terrorist acts.

\section{c. Special Detachment 88 Anti Terror (Densus 88 AT)}

The Special Detachment 88 Anti-Terror is a countermeasure against terrorism within the Indonesian Police (Polri). Densus 88 AT carried out investigations, namely, carrying out actions related to operations in the field. The role of Special Detachment 88 AT cannot be separated from the role of the National Police as law enforcement and maintaining public order, the function of the PolicePolice, namely as one of the functions of the state government in the field of maintaining general security and order, law enforcement, protection, protection, and services to the community. ${ }^{92}$ The police function must pay attention to the spirit of upholding human rights, law, and justice. ${ }^{93}$ Meanwhile, the PolicePolice aims to realize domestic security, which includes maintaining public order and order, law and order, protection, protection, and services to the community, and the maintenance of community peace by upholding human rights. ${ }^{94}$

As a counterterrorism agency within the National Police, Densus 88 AT has the task of dealing with all forms of terrorist threats, including bomb threats and hostage-taking, which are called terrorist acts, which is dealing with these terrorist acts, Densus 88 AT requires intelligence reports as initial information to carry out actions. ${ }^{95}$ With the incidents during Densus 88 AT carrying out terrorist eradication operations, which resulted in many casualties, it is essential to carry out a structural and systematic paradigm reform policy on the body of Special Detachment 88 AT so that counterterrorism efforts are more targeted, with high respect against human rights, especially the right to life. ${ }^{96}$

\section{Terrorism in Legal Perspective}

Terrorism is an act that is very detrimental to society, both national and international, including crimes against human rights. ${ }^{97}$ The Bali bombing case on 12 October 2002 was the government's reason for issuing Perpu 1/2002, which was later stipulated as Law 15/2003. Also, the reasons for stipulating legal products at the level of laws related to terrorism, namely: ${ }^{98}$ First, the Government of the Republic of Indonesia's pressure to have a relatively fixed rule of law as a reference in handling terrorism crimes. Because previously, there was no known criminal act of terrorism in the criminal law system in Indonesia. Second, the spirit of reform that engulfs Indonesian society strongly encourages the agenda of law enforcement and civil supremacy, which begins with the issuance of regulations for handling terrorism crimes that prioritize the legal process (pro-Justitia) and abandon the defense (military) approach.

\footnotetext{
92 Article 2 Law Number 2 of 2002 concerning the State Police of the Republic of Indonesia, State Gazette of the Republic of Indonesia of 2002 Number 2, Supplement to the Republic of Indonesia Number 4168, referred to as Law 2/2002.

${ }^{93}$ Explanation of Article 2 Law 2/2002.

${ }^{94}$ Article 4 Law 2/2002.

${ }^{95}$ Ryan Faizul Fajri, Peran Intelejen Densus 88 Dalam Menanggulangi Tindak Pidana Terorisme, Universitas Lampung, Bandar Lampung, 2018.

${ }^{96}$ Zainal Muhtar, "Eksistensi Densus 88: Analisis Evaluasi Dan Solusi Terkait Wacana Pembubaran Densus 88," Supremasi Hukum: Jurnal Kajian Ilmu Hukum, vol. 3, June 1, 2014, http://ejournal.uin-suka.ac.id/syariah/Supremasi/article/view/1953.

97 Article 3 Deklarasi Universal Hak Asasi Manusia menentukan, "Setiap orang berhak atas kehidupan, kebebasan dan keselamatan sebagai individu".

98 “Analisa Pelibatan TNI AD Dalam Menanggulangi Terorisme Di Indonesia (Studi Wilayah Kodim 0612/TSM),” Jurnal Prodi Strategi Pertahanan Darat, n.d.
} 
Thus, Perpu 1/2002 began to introduce the term terrorism as a crime. But lately, acts of terrorism in Indonesia have even grown. Data from the National Counterterrorism Agency (BNPT) states that from 2001-2014, at least 950 people were involved in the terrorism movement in Indonesia (BNPT, 2014). ${ }^{99}$ As a response to Law 15/2003, the National Police established a particular organ in handling the anti-terrorism movement, namely Densus 88 AT. Thus, juridically, countermeasures against terrorism in Indonesia by the police institution are the main actors authorized to deal with terrorism movements in Indonesia. The existence of an anti-terror unit in the ranks of the TNI AD, which has previously been prepared as an anti-terror force, can only play a role under certain conditions. The role of the TNI in dealing with terrorism is clearly stated in Article 7 paragraph (2) letter b number 3 of Law Number 34 of 2004 concerning the Indonesian National Army (State Gazette of the Republic of Indonesia of 2004 Number 127, Supplement to the State Gazette of the Republic of Indonesia Number 4439 , in the future referred to as Law 34/2004), states "The main tasks as referred to in paragraph (1) are carried out by military operations other than war, namely to: overcome acts of terrorism". Thus, the involvement of the TNI in dealing with terrorism is legitimate".

In-Law 3/2002, it is stated that the national defense system is facing military threats. ${ }^{100}$ Placing the TNI as the main component supported by a reserve component and supporting components. Meanwhile, the state defense system in facing non-military threats places government institutions outside the defense field as the main element, according to the form and nature of the threats faced supported by other elements of the nation's power. Nonmilitary threats, which are also called military operations other than war, include overcoming acts of terrorism and assisting the Indonesian National Police in security and public order duties as regulated in law.

Non-military threats, such as the series of bombings that occurred in the territory of the Republic of Indonesia, have caused fear to the community because they resulted in the loss of life and property loss, which had an impact on social, economic, political life, and Indonesia's relations with the international community. As one of how terrorism perpetrators carry out their actions in several countries, Bomb detonation is also an act of terrorism in Indonesia. The Indonesian government is obliged to protect its citizens from every threat of crime, both national, transnational, and international in nature. In reality, the government chooses the Justia approach as the primary approach in dealing with acts of terrorism, emphasizing that the handling of acts of terrorism must be based on a legal approach. This emphasizes that the PolicePolice, not the army, can only carry out the active handling of acts of terrorism. Thus, by the provisions of legislation related to terrorism, the TNI AD is affiliated with the State Intelligence Agency (BIN) and the Strategic Intelligence Agency (BAIS) as elements of early detection and prevention of acts of terrorism. ${ }^{101}$

From the Indonesian army's perspective, terrorism is a way of thinking and acting that uses terror as a technique to achieve goals (Bujuknik TNI AD on Anti-Terror, 2000). The means to achieve an unconstitutional goal, including acts of terror, constitute a threat to national defense and security stability. The facts of acts of terrorism are a threat to the stability of national defense and security. Concretely, terror in Indonesia is always actualized by trained terrorists who have attended military education and can use dangerous weapons and munitions. Also, the large logistics supply from international networks makes the terrorism movement in Indonesia very dangerous. Even though the cells of the members of the terrorism network were successfully paralyzed and arrested, it does not mean that the activities of the terrorist group network have been weakened.

\footnotetext{
${ }^{99}$ Ibid.

${ }^{100}$ Military threats are threats that use organized armed force, which is considered to have the capability of endangering the sovereignty of the state, the country's territorial integrity, and the safety of the entire nation.

${ }^{101}$ Mochammad Afifuddin \& Ari Priyudono, Op.cit, pg. 4.
} 
Also, the bombing at the JW Marriot Hotel on 5 August 2003 which killed the suicide bombers and 12 (twelve) others and 150 (one hundred and fifty) people were injured, the Thamrin bomb in the Sarinah area which exploded because of Starbuck Coffee. and the police station and cases in Tasikmalaya Regency are facts that show that acts of terrorism that have been detected still further confirm that acts of terrorism can still be carried out. This confirms that the threat of terrorism cannot be underestimated because its impact can threaten economic stability, politics, and national defense and security. Thus, the role of TNI, in this case, plays a significant role as an element of early detection and prevention of acts of terror. Also, the criminal act of terrorism is a threat to human values that requires law as a means of overcoming it.

A criminal act of terrorism cannot be equated with a crime in general, for example, the crime of murder. The crime of murder can only become terrorism is carried out to create an atmosphere of terror by using violence or threats of violence that cause fear to people en masse and on a large scale. ${ }^{102}$ Terrorism has become a common enemy because it is a severe crime, contrary to human values with reason: ${ }^{103}$

1. Democracy and political violence are incomplete if they do not feel safe. Whereas the reform movement aims to make all of us safe at home and more comfortable in the state's life. We all take responsibility for fighting terrorism that wants to feel safe;

2. Terrorism is a crime against humanity in the form of an organized movement. Currently, terrorism has a wide and global network that threatens national and international peace and security.

Law enforcement in eradicating criminal acts of terrorism is carried out through formal steps, namely the operation of the criminal justice system (SPP). SPP is a system in society to overcome ${ }^{104}$ Crime. ${ }^{105}$ The purpose of this SPP is to:

1. Prevent people from becoming victims of crime;

2. Resolving crimes that occurred so that the public was satisfied that justice was served and the guilty were convicted; and

3. Make sure that those who have committed crimes do not repeat their crimes.

According to Joseph Goldstein, in realizing justice, there are 3 (three) types of law enforcement, namely: ${ }^{106}$ Total Enforcement (namely: law enforcement is carried out under the law), Full Enforcement, and Actual Enforcement. In realizing justice, law enforcement, especially against acts of terrorism that threaten security, is of particular concern, involving various elements, including elements of the TNI. The involvement of the TNI in countering acts of terrorism, there are two points of view in tackling it, namely: ${ }^{107}$ First, terrorism is a criminal act. This perspective places the PolicePolice and law enforcement agencies as leading agents in countering acts of terrorism. The TNI and other institutions' involvement is to assist the PolicePolice and other law enforcement institutions in combating acts of terrorism. Second, terrorism with a security approach that sees terrorists as a threat to national

\footnotetext{
102 Muhammad Ali Zaidan, Op.cit.

${ }^{103}$ Randi Pradityo, "Radikalisme Islam Dan Upaya Deradikalisasi Faham Radikal,” Jurnal Walisongo, accessed February 10, 2021,

https://www.google.com/search?q=Randi+Pradityo $\% 2 \mathrm{C}+$ Radikalisme+Islam+dan+Upaya+Deradikalisasi+Faham+Radikal $\%$ 2C+Jurnal+Walisongo\&oq=Randi+Pradityo\%2C+Radikalisme+Islam+dan+Upaya+Deradikalisasi+Faham+Radikal\%2C+Jur nal+Walisongo\&aqs=chrome..69i57.934j0j4\&sourceid=chrome\&ie=UTF-8.

${ }^{104}$ Overcoming means efforts to control crime so that it falls within the limits of community tolerance.

105 Boy Mardjono Reksodiputro, Hak Asasi Manusia dalam Sistem Peradilan Pidana, Kumpulan Karangan, Buku Ketiga, Jakarta: Pusat Pelayanan Keadilan dan Pengendalian Hukum (d/h. Lembaga Kriminologi Indonesia), 1994, pg. 84.

${ }^{106}$ George F. Cole, Criminal Justice, Law, and Politic, Montreal, California, USA: Brooke/Cole Publishing Company, 1984, pg. 74.

107 Eka Martiana Wulansari, Urgensi Keterlibatan Tentara Nasional Indonesia (TNI) Dalam Penanggulangan Aksi Terorisme, Prosiding Seminar Ilmiah Nasional: "MEmbangun Paradigma Kehidupan Melalui Multidisiplin Ilmu", Pascasarjana Universitas Pamulang, Juli 2017, pg. 244-245.
} 
security. In this perspective, the state conducts an assessment of the security situation, which is the basis for deploying security instruments, including military forces, in countering acts of terrorism. Suppose the state determines that security situations have been threatened and takes political decisions to mobilize military force. In that case, terrorists are no longer seen as criminal acts, so that laws that view terrorism as a criminal act are no longer valid.

Therefore, for criminal acts of terrorism, law enforcement must be strictly enforced by upholding the rule of law's principles with a positive paradigm. Thus, the involvement of the TNI in handling acts of terrorism from a legal perspective is constitutional under the duties and functions of each institution that is given authority by the laws and regulations.

\section{Conclusion}

The main task of the TNI is to maintain the Republic of Indonesia's integrity and uphold the country's sovereignty. Thus, the involvement of the TNI in the context of handling acts of terrorism is a synergy with government agencies or non-ministerial government agencies that are assigned tasks by laws and regulations, as has been done by the TNI in coordination with the PolicePolice in handling several acts of terrorism that have occurred. The TNI is very appropriate to be involved in handling acts of terrorism. The involvement of the TNI in overcoming acts of terrorism as it functions as a major component in the national defense system upholds state sovereignty, maintains the territorial integrity of the Republic of Indonesia, and protects the entire nation and all spilled Indonesian blood based on Pancasila and the 1945 Constitution. Thus, the involvement of the TNI in eradicating acts of terrorism, in the context of non-OMSP law enforcement operations, except in its development, acts of terrorism have threatened the existence of the Republic of Indonesia or extraordinary circumstances/conditions have occurred constitutionality to maintain the unity and integrity of the Republic of Indonesia. This is following the specific nature of the TNI (lex specialis) in carrying out its duties which require expertise.

\section{A. Books}

\section{Bibliography}

Aritonang, Jan S., Sejarah perjumpaan Kristen dan Islam di Indonesia. Jakarta: BPK Gunung Mulia, 2006.

Bakti, Agus Surya, Deradikalisasi Nusantara, Perang Semesta Berbasis Kearifan Lokal, Melawan Radilisasi dan Terorisme, Jakarta: Daulat Press, 2016.

Bjorgo, Tore, Root Causes of Terrorism: Myths, Reality, and Ways Forward, New York: Routledge, 2005.

Cole, George F., Criminal Justice, Law and Politic, Montreal, California, USA: Brooke/Cole Publishing Company, 1984.

Golose, Petrus Reinhard, Deradikalisasi Terorisme. Humanus Soul Approach dan Menyentuh Akar Rumput, Jakarta: Yayasan Pengembangan Ilmu Kepolisian (YPKIK), 2010.

Reksodiputro, Boy Mardjono, Hak Asasi Manusia dalam Sistem Peradilan Pidana, Kumpulan Karangan, Buku Ketiga, Jakarta: Pusat Pelayanan Keadilan dan Pengendalian Hukum (d/h. Lembaga Kriminologi Indonesia), 1994.

Sari, Angga Putri Permata, "Akar Permasalahan Terorisme di Indonesia" Modernisasi, Represi Politik, dan Tujuan Strategis Penggunaan Metode Teror Sebagai Faktorfaktor Struktural dan Agensial yang Berkonstribusi Pada Kemunculan Terorisme di Era Komando Jihad dan Kelompok Usroh, Program Studi Pascasarjana Kajian Terorisme dalam Keamanan Internasional Departemen Ilmu Hubungan Internasional Fakultas Ilmu Sosial dan Ilmu Politik Universitas Indonesia, 2011.

Soekanto, Soerjono dan Sri Mamudji, Penelitian Hukum Normatif, Jakarta, Raja Grafindo Persada, 1985. 
Sunggono, Bambang, Metodologi Penelitian Hukum, Jakarta, Raja Grafindo Persada, 1997. Yunanto, Sri, Angel Damayanti, Indah Novitasari, Ancaman dan Strategi Penanggulangan Terorisme di Dunia dan Indonesia, Institute For Peace and Security Studies (IPSS) bekerjasama dengan CV. Multi Inovasi Mandiri (MIM), Cetakan I: 2017.

\section{B. Journal}

Arifin, Samsul. "Perlindungan Hukum Terhadap Anak Dalam Tindak Pidana Terorisme." Jurnal Panorama Hukum 5, no. 1 (June 5, 2020): 49-62. https://doi.org/10.21067/jph.v5i1.4317.

Aulia Rosa Nasution. "TERORISME SEBAGAI 'EXTRAORDINARY CRIME' DALAM PERSPEKTIF HUKUM DAN HAK ASASI MANUSIA ."Jurnal Hukum Responsif. Accessed February 10 ,

2021. http://jurnal.pancabudi.ac.id/index.php/hukumresponsif/article/view/165.

Jazuli, Ahmad. "STRATEGI PENCEGAHAN RADIKALISME DALAM RANGKA PEMBERANTASAN TINDAK PIDANA TERORISME (Prevention Strategy of Radicalism in Order To Wipe Out The Terrorism Crime)." Jurnal Ilmiah Kebijakan $\begin{array}{lllll}\text { Hukum. } & \text { Vol. } & 10, & \text { February } & 13,\end{array}$ https://doi.org/10.30641/KEBIJAKAN.2016.V10.197-209.

Junaid Jurusan Pendidikan Agama Islam DPK UIM Gazali UIN Alauddin Makassar Alamat, Hamzah AL, and jipang raya. "PERGERAKAN KELOMPOK TERORISME DALAM PERSPEKTIF BARAT DAN ISLAM.” Sulesana: Jurnal Wawasan Keislaman. Vol. 8, December 1, 2013. https://doi.org/10.24252/.V8I2.1285.

Moghaddam, Fathali M. "The Staircase to Terrorism a Psychological Exploration." American Psychologist, February 2005. https://doi.org/10.1037/0003-066X.60.2.161.

Muhtar, Zainal. "Eksistensi Densus 88: Analisis Evaluasi Dan Solusi Terkait Wacana Pembubaran Densus 88." Supremasi Hukum: Jurnal Kajian Ilmu Hukum. Vol. 3, June 1, 2014. http://ejournal.uin-suka.ac.id/syariah/Supremasi/article/view/1953.

Rahardanto, Michael Seno. "MENGKAJI SEJUMLAH KEMUNGKINAN PENYEBAB TINDAK TERORISME: KAJIAN SOSIO-KLINIS.” EXPERIENTIA : Jurnal Psikologi Indonesia. Vol. 1, November 6, 2012. https://doi.org/10.33508/EXP.V1I1.54.

Randi Pradityo. "Radikalisme Islam Dan Upaya Deradikalisasi Faham Radikal." Jurnal Walisongo. Accessed $\quad$ February 2021. https://www.google.com/search?q=Randi+Pradityo\%2C+Radikalisme+Islam+dan+Upay $\mathrm{a}+$ Deradikalisasi+Faham+Radikal\%2C + Jurnal+Walisongo\&oq=Randi+Pradityo $\% 2 \mathrm{C}+\mathrm{R}$ adikalisme+Islam+dan+Upaya+Deradikalisasi+Faham+Radikal\%2C+Jurnal+Walisongo $\&$ aqs $=$ chrome..69i57.934j0j4\&sourceid=chrome\&ie=UTF-8.

Rokhmad, Abu. "RADIKALISME ISLAM DAN UPAYA DERADIKALISASI PAHAM RADIKAL." Walisongo: Jurnal Penelitian Sosial Keagamaan 20, no. 1 (May 30, 2012): 79. https://doi.org/10.21580/ws.20.1.185.

Setiawan, Muhammad Arif. "Kriminalisasi Terorisme Di Indonesia Dalam Era Globalisasi." Jurnal Hukum IUS QUIA IUSTUM 9, no. 21 (September 21, 2002): 67-86. https://doi.org/10.20885/iustum.vol9.iss21.art6.

Widiatmaja, Aji, and Ulul Albab. "Indonesia Di Era Susilo Bambang Yudhoyono (SBY) Dan Joko Widodo: Kebijakan Luar Negeri Di Tengah Dinamika Lingkungan [Indonesia under Susilo Bambang Yudhoyono (SBY) and Joko Widodo: Foreign Policy in the Middle of Regional Strategic Environment Dynamics]." Jurnal Politica Dinamika Masalah Politik Dalam Negeri Dan Hubungan Internasional 10, no. 1 (May 31, 2019): 77-93. https://doi.org/10.22212/jp.v10i1.1313.

Yunus, A Faiz. "Radikalisme, Liberalisme Dan Terorisme: Pengaruhnya Terhadap Agama 
Islam.” Jurnal Online Studi Al-Qur An 13, no. 1 (January 1, 2017): 76-94. https://doi.org/10.21009/jsq.013.1.06.

\section{Law and Other Regulations}

Government Regulation in Lieu of Law Number 1 of 2002 concerning the Eradication of Criminal Acts of

Terrorism (State Gazette of the Republic of Indonesia of 2002 Number 106) Presidential Regulation Number 46 of 2010 concerning the National Counterterrorism Agency, which was later amended by Presidential Regulation Number 12 of 2012 concerning Amendments to Presidential Regulation Number 46 of 2010 concerning the National Counterterrorism Agency (State Gazette of the Republic of Indonesia of 2012 Number 30).

Constitutional Court Decision Number 55 / PUU-XVI / 2018, dated 30 October 2018.

1945 Constitution of the Republic of Indonesia.

Law Number 15 of 2003 concerning Stipulation of Government Regulation in Lieu of Law Number 1 of 2002 concerning the Eradication of Criminal Acts of Terrorism Into Law (State Gazette of the Republic of Indonesia of 2003 Number 45, Supplement to the State Gazette of the Republic of Indonesia Number 4284).

Law Number 2 of 2002 concerning the State Police of the Republic of Indonesia, State Gazette of the Republic of Indonesia of 2002 Number 2, Supplement to the Republic of Indonesia Number 4168.

Law Number 34 of 2004 concerning the Indonesian National Army (State Gazette of the Republic of Indonesia of 2004 Number 127, Supplement to the State Gazette of the Republic of Indonesia Number 4439).

Law Number 5 of 2018 concerning Amendments to Law Number 15 of 2003 concerning Stipulation of Government Regulations in Lieu of Law Number 1 of 2002 concerning the Eradication of Criminal Acts of Terrorism Into Law (State Gazette of the Republic of Indonesia of 2018 Number 92, Supplement to the State Gazette Republic of Indonesia Number 6216.

\section{Internet}

Hertanto, L., Abu Dujana anggap polisi toghut, http://news.detik.com/read/2007/06/23/173328/797030/10/abu-dujana-anggappolisi-toghut, 2007, diunduh 24 Oktober 2020.

Kahneman, D., Maps of bounded rationality: A perspective on intuitive judgment and choice. Diunduh dari http://www.nobelprize.org/nobel_prizes/economics/laureates/2002/kahnemannlecture.pdf, 2002, diunduh 24 Oktober 2020.

Nelson, J.-Pallmayer, Is religion killing us?, (Terjemahan: Hatib Rachmawan, Bobby Setiawan), Yogyakarta: Pustaka Kahfi, 2007.

Tajfel, H., J. Turner, An integrative theory of intergroup conflict, http://dtserv2. compsy.unijena.de/ss2009/sozpsy_uj/86956663/content.nsf/Pages/58BD3B477ED06679C12 5759B003B9C0F/\$FILE/Tajfel\%20Turner\%201979.pdf, 1979, diunduh 24 Oktober 2020. 
